\title{
'The middling order are odious characters': social structure and urban growth in colonial Charleston, South Carolina
}

\author{
EMMA HART \\ Dept of Modern History, University of St Andrews, St Katharine's Lodge, \\ St Andrews, Fife, KY16 9AL
}

\begin{abstract}
In recent years, the idea that Britain and its northern American colonies were part of a single 'British Atlantic world' has provided historians of both the Old World and the New with a novel perspective from which to explore their subjects during the long eighteenth century. With a case study of Charleston, South Carolina, this essay extends British categories of analysis across the Atlantic to uncover the origins of an American middle class. Emphasis is placed on the simultaneous consideration of all arenas of identity formation, with a view to demonstrating that examining either the cultural sphere or the economic one cannot bring a genuine understanding of the coherence of this eighteenth-century middling sort. Investigating the emergence of this social group in the widest possible sense, I show how the economic experience of these middling people forged common values which then found their expression in the cultural and political sphere. Since this middle sort achieved such coherence before 1776 I suggest that we must move away from accounts that depict colonial society as a place of binary opposites and occupational groupings, for such models cannot convey the complexity of the British Atlantic urban society that took shape during this era.
\end{abstract}

During a sojourn in Charleston, South Carolina in 1773, Bostonian Josiah Quincy proclaimed that the town's 'middling order' were 'odious characters', easily distinguished from the region's 'yeomanry and husbandmen'. Quincy's observations of this colony's social structure emphasized characteristics noted by commentators who had previously cast their eye across early America's towns and cities. Already in 1751, just 20 years after Charleston's white population had begun to experience significant growth, Governor James Glen noted that the town harboured a 'middle sort'. Meanwhile, Benjamin Franklin, writing in the late 1740s, saw in Philadelphia a town partly composed of 'those Great and rich Men, Merchants and others', but also made up of 'middling 
People... Shopkeepers, and Tradesmen'. ${ }^{1}$ Early American urban society was evidently becoming more stratified into recognizable collectives of people, one of which was situated in the middle. And, within this middling order, towndwelling colonists were now united enough to be part of a group that superseded the particular interests and lifestyles fostered by their occupations.

In contrast, in their reinterpretations of earlier models that stressed middle-class consensus in colonial America, historians have described a very different social structure. Because of a strong belief in the power of occupation to divide colonists into interest groups, they have asserted that 'the contradictions and ambiguities of middling status were ... irreducible' in the eighteenth-century American city. ${ }^{2}$ Thus, artisans are treated as one of the most coherent groups in early America, united by their identity as handicraftspeople and set apart from those who traded for a living middling and poorer artisans remained more united by work than divided by wealth or status. On a broader canvas, viewing colonial society as being made up of such interest groups dovetails neatly with the popular opinion that social structure and power relations in colonial America are best understood in binary terms - of elites and lower sorts, mechanics and merchants, or, in the case of the southern colonies, of whites and blacks, free and unfree. Indeed, it was not until the Revolution and the early nineteenth century, historians argue, that this society of opposites was transformed into something more complex; an entity with a middle group that transcended occupational barriers and regional constraints. ${ }^{3}$

However, the most recent investigations into early American social structure (and in particular into the middling sort) have sought the roots of these more sophisticated nineteenth-century patterns in the prerevolutionary era. Most notably, Dallett Hemphill has, with her recent history of American manners, moved enquiry about the terms of class

1 'Journal of Josiah Quincy Jr.', Proceedings of the Massachusetts Historical Society, 49 (1916), 424-81; Glen, 'Governor James Glen's valuation, 1751', in H. Roy Merrens (ed.), The Colonial South Carolina Scene (Columbia, 1977), 185; Benjamin Franklin as quoted in Gary B. Nash, The Urban Crucible: The Northern Seaports and the Origins of the American Revolution (Cambridge, MA, 1979), 232.

2 Louis Hartz, The Liberal Tradition in America (New York, 1955); Robert E. Brown, Middle Class Democracy and the Revolution in Massachusetts, 1691-1780 (Ithaca, 1955); Stuart M. Blumin, The Emergence of the Middle Class: Social Experience in the American City, 1760-1900 (Cambridge, 1989), 30-8.

${ }^{3}$ Howard Rock and Paul Gilje (eds.), American Artisans: Crafting a Social Identity (Baltimore, 1995); Gary Nash, 'Artisans and politics in eighteenth-century Philadelphia', in idem, Race, Class, and Politics: Essays on American Colonial and Revolutionary Society (Urbana, 1986), 24368; Gary Nash, The Urban Crucible: Social Change, Political Consciousness, and the Origins of the American Revolution (Cambridge, MA, 1979); Rhys Isaac, The Transformation of Virginia, 17401790 (Chapel Hill, 1982); Gordon S. Wood, The Radicalism of the American Revolution (New York, 1992); Joyce Appleby, 'The social consequence of American revolutionary ideals in the early republic', in Burton J. Bledstein and Robert D. Johnston (eds.), The Middling Sorts: Explorations in the History of the American Middle Class (New York, 2001), 31-49; Blumin, The Emergence of the Middle Class; Mary P. Ryan, Cradle of the Middle Class: The Family in Oneida County, New York, 1790-1860 (Cambridge, 1983). 
formation in colonial America into new, cultural, pastures. ${ }^{4}$ In many ways, she has followed the example of historians interested in Britain's middling sorts of the same era. Closely linking their subjects to the urban environment, these scholars have explored the construction of a middling identity not just in the cultural, but also in the economic and political domain. In the economic sphere, they have delved into the character of the household economy with the intention of demonstrating that the particular occupation of the male head was less important than the variety of occupations that an entire family pursued in the name of their financial security. What defined this middle sort was their entrepreneurial behaviour within burgeoning urban environments, their ability to disregard the constrictions of occupation and the willingness of their womenfolk to participate in business activity. ${ }^{5}$ Middling people's status as 'independent trading householders' who found their modest success in the town then began to affect the cultural and political outlook of some among their ranks. Reflecting their commitment to entrepreneurship and active business, certain middling folk rejected the example of the leisured elites, shunning vacuous cultural pursuits such as balls in favour of clubs and societies that still had a social purpose, but which also had charitable goals and were designed to help out less fortunate townspeople. In other words, they rejected indiscriminate emulation of their superiors as the obvious cultural choice. On the political scene, middling people also began to make their own particular mark. Using new and old structures of local government, they manoeuvred themselves into office, promulgated a particular ideology of civic responsibility and promptly came to blows with those local elites who had traditionally stood at the helm of such institutions. $^{6}$

${ }^{4}$ Dallett Hemphill, Bowing to Necessities: A History of Manners in America, 1620-1860 (Oxford, 1999). See also Sven Beckert, 'Comments on studying the middle class in the modern city', Journal of Urban History, 31 (2005), 396.

5 Peter Earle has argued that 'the choking blanket of corporation and fraternalism that smothered the business lives' of middling people was now cast off. See Earle, The Making of the English Middle Class: Business, Society and Family Life in London, 1660-1730 (Berkeley, 1989), 335; Shani D'Cruze, 'Middling sorts in eighteenth-century Colchester', in Jonathan Barry and Christopher Brooks (eds.), The Middling Sort of People: Culture, Society and Politics in England, 1550-1800 (Basingstoke, 1994), 184 and 188-9; Margaret Hunt, The Middling Sort: Commerce, Gender and, and the Family in England, 1680-1780 (Los Angeles, 1996), 139.

${ }^{6}$ On the cultural moves of the middling sort see Peter Clark, British Clubs and Societies, 1580-1800: The Origins of an Associational World (Oxford, 2000); Kathleen Wilson, 'Urban culture and political activism in England: the example of voluntary hospitals', in Eckhart Hellmuth (ed.), The Transformation of Political Culture in Late Eighteenth Century England and Germany (Oxford, 1989), 165-84; Hunt, Middling Sort, 101-24; Lorna Weatherill, Consumer Behaviour and Material Culture in Britain, 1660-1770 (London, 1996); Earle, The Making of the English Middle Class; Elizabeth McKellar, The Birth of Modern London (Manchester, 1999). On middling politics see Jonathan Barry, 'Bourgeois collectivism? Urban association and the middling sorts', in Barry and Brooks (eds.), The Middling Sort of People, 84-112; Nicholas Rogers, 'The middling sort in eighteenth-century politics', in Barry and Brooks (eds.), The Middling Sort of People; Kathleen Wilson, The Sense of the People: Politics, Culture and Imperialism in England, 1715-1785 (Cambridge, 1995); John Walter and Michael J. Braddick (eds.), Negotiating Power in Early Modern Society (Cambridge, 2001). 
Through a case study of Charleston, South Carolina, this essay deploys these British categories of analysis in a New World context to reveal how an urban middling sort was already a vital presence in colonial America's social structure before 1776. Emphasis is placed on the simultaneous consideration of all arenas of identity formation, with a view to demonstrating that examining either the cultural sphere or the economic one cannot bring a genuine understanding of the coherence of this eighteenth-century middling sort. Investigating the emergence of this social group in the widest possible sense, I show how the economic experience of these middling people forged common values which then found their expression in the cultural and political sphere. Since this middle sort achieved such coherence before 1776 we must move away from accounts that depict colonial society as a place of binary opposites and occupational groupings, for such models cannot convey the complexity of the urban social structure in this era. This investigation also reveals the degree to which middling Charlestonians' distinctive socio-economic and political characteristics were dependent upon their ties to a thriving urban environment. That it is possible to trace such processes of self-definition among urbanites both in early America and in Britain is critical to our understanding of the relationship between English-speaking societies in the New and Old Worlds. In particular, highlighting the similarities in urban social process across this British Atlantic illustrates how expanding towns, wherever they were, had a comparable impact on their locales. For sure, there were many differences between colonial and British social structure - just as there were variations in the social structures of the many regions and provinces within each geographical entity. But, rather than Revolution, or some more generalized cultural imperative that spanned all of society, it was towns that fostered the creation of a British Atlantic middling sort who articulated their identity through similar channels, even when they lived in the farthest flung corners of an expanding world. ${ }^{7}$ The roots of the American middle class, like the roots of the British middle class, were tangled up in a transatlantic experience of urbanization.

\section{Independent traders}

With the discovery of rice as South Carolina's staple export in the decades around 1700 came growing prosperity for the colony and its chief town, Charleston. Conveniently located at the mouth of two major rivers, the

7 Although historians have identified a process of cultural 'Anglicization' in eighteenthcentury America, they have in most other respects been wont to stress the exceptional nature of colonial society. For a discussion of exceptionalism see Joyce Chaplin, 'Expansion and exceptionalism in early American history', Journal of American History, 89 (2003), 1-25. Those who have recently made exceptional arguments include Michael Zuckerman, 'Tocqueville, Turner, and turds: four stories of manners in early America', Journal of American History, 84 (1998), 13-42; Keith Wrightson, 'Class', in David Armitage and M.J. Braddick (eds.), The British Atlantic World, 1500-1800 (Basingstoke, 1999). 
Table 1: Population growth in selected British and American towns

\begin{tabular}{lcl}
\hline \hline Town & Population c. 1700 & Population c. 1800 \\
\hline Boston & 7,500 & 24,937 \\
Bristol & 13,482 & 61,153 \\
Charleston & 1,500 & 18,824 \\
Colchester & 6,647 & 11,520 \\
Glasgow & 18,000 & 77,058 \\
New York & 4,500 & 60,489 \\
Newcastle & 11,617 & 33,048 \\
Philadelphia & 2,450 & 51,938 \\
Shrewsbury & 6,867 & 14,739 \\
\hline \hline
\end{tabular}

Source: Gary Nash, The Urban Crucible: The Northern Seaports and the Origins of the American Revulution (Cambridge, MA, 1979), Appendix, Table 13; Converse Clowse, Measuring Charleston's Overseas Commerce, 1717-1767 (Washington, DC, 1981), Table A-11; United States Census for 1800; John Langton, 'Urban growth and economic change: from the late seventeenth century to $1841^{\prime}$, in Peter Clark (ed.), The Cambridge Urban History of Britain, vol. II: 1500-1840 (Cambridge, 2000), Table 14.4, 473-4.

Ashley and the Cooper, Charleston became a major hub in the Atlantic trade, expanding to become mainland British America's fourth largest town. Throughout the eighteenth century, it sustained an impressive rate of population growth. By 1770, it had some 12,000 residents, half of whom were enslaved and free African-Americans. Since the region as a whole was home both to colonial America's wealthiest settlers and to many slaves who had nothing, a huge social and economic gulf separated rich whites from their chattel labourers. Yet, by mid-century, wealth distribution patterns among the free population in the Charleston district of South Carolina make it difficult to view this entire society as being characterized by polar opposites. Where the wealthiest decile of the white population owned over half of all wealth, and the poorest quarter just 1 per cent, there were still 65 per cent of whites in the middle with 45 per cent of assets distributed among them. ${ }^{8}$

${ }^{8}$ Robert Olwell, Masters, Slaves, and Subjects: The Culture of Power in the South Carolina Low Country (Ithaca, 1998); Philip D. Morgan, 'Black life in eighteenth-century Charleston', Perspectives in American History, n.s. 1 (1984), 187-232; Richard Waterhouse, 'Economic growth and changing patterns of wealth distribution in colonial lowcountry South Carolina', South Carolina Historical Magazine, 89 (1988), 203-17; Converse Clowse, Economic Beginnings in Colonial South Carolina, 1670-1730 (Columbia, 1971); Alice Hanson Jones, The Wealth of a Nation to Be: The American Colonies on the Eve of the Revolution (New York, 1980), Table 7.1, 220, also reveals a more complex wealth distribution pattern. As Hanson Jones' statistics show, there were regional variations, and New England's wealth distribution was more even than that of the middle colonies or the south. 
Many among this last group of the Charleston population - white people of modest yet not vast wealth - had achieved their position through a strategy of entrepreneurship within the growing town. They had created 'independent trading households' that thrived through their embrace of the many and varied economic possibilities on offer in Charleston. The story of John and Violetta Wyatt ably illustrates the economic diversification characteristic of this emerging group. John Wyatt arrived in the low country from England in 1770, and established himself as a house carpenter and joiner in the town. Marrying the daughter of a local blacksmith, he inherited a plantation and a number of slaves, but sold the rural land and put his African-American labour to work in his shop. Extra wealth was generated by starting up a carting business, a saw mill and a distillery, and by re-exporting exotic woods from the Caribbean. The saw mill was expressly erected so as to 'get the better' of his competitors in the carpentry business. Wyatt further built and owned a clutch of rental properties in Charleston. John Wyatt's widow Violetta, and his motherin-law, also contributed to the family income by hiring out skilled slaves, lending money at interest and taking in boarders. ${ }^{9}$

The Wyatts were not alone in the wide-ranging nature of their business interests. Among their immediate contemporaries in the larger Charleston trading community, newspaper advertisements reveal that over 80 per cent proclaimed that, in addition to specialist skills, they offered further goods or services. Clockmakers, silversmiths, coachmakers, gunsmiths, gardeners, upholsterers and paperhangers all became regular importers and advertisers of British goods and groceries. Carpenter, surveyor and architect of the Charleston Exchange, William Rigby Naylor, advertised in 1771 that he had 'a large and complete... assortment' of carpenter's tools, bigger than any 'as ever was imported into this province'. Others peddled limes, sugar, rum, fabric, cheese and tea. ${ }^{10}$ If they did not have the capital or the desire to enter the import trade, there were plenty of other opportunities for tradesmen within Charleston's service economy. Occasionally, these side enterprises followed a customary pattern of diversification already visible in the Old World's towns; blacksmiths often opened inns for example. ${ }^{11}$ One of the more popular sidelines among town traders, however, was accounting. As Margaret Hunt has shown, accounting skills were a particular feature of the middling trading household who, juggling many business interests in an economic environment often plagued by uncertainty, had to keep a firm handle on

${ }^{9}$ Charleston County Chancery Court Bills of Complaint, 1, 10, Executors of John Wyatt v. Executors of Thomas and Barnard Richardson, 1796, South Carolina Department of Archives and History, Columbia, SC.

10 Advertisements of William Rigby Naylor, South Carolina Gazette, 13 Jun. 1771; South Carolina and American General Gazette, 10 Aug. 1772.

11 Advertisement of Michael Muckinfuss, South Carolina Gazette, 9 May 1768. 
income and outgoings. ${ }^{12}$ South Carolina upholsterer John Blott advertised that he was willing to take on 'the care of one or two sets of books, of principal houses [of] merchants' ${ }^{13}$ Middling wives were also expected to be skilled in this arena, and Violetta Wyatt apologized after her husband's death for not being able to understand his books, excusing herself on the grounds that 'she was always much occupied at home in the duties of managing'. ${ }^{14}$ Loyalist shipwright Daniel Manson's wife, however, capably managed her husband's financial affairs when, after his flight from Charleston, he fell into a deep depression and could not bear to confront the 'low state' of his fortunes. ${ }^{15}$

As the economic lives of these families illustrate, a woman's work and abilities within the urban economy were critical to a household's middling status - the role of Violetta Wyatt was not a singular one. Unlike in elite circles, there was little perception among Charleston's middling sorts that economic activity outside of the domestic sphere was inappropriate. Although there were some activities considered more suitable for women than others (such as teaching, millinery and retailing), productive employment was paramount if the security of the middling household was to be maintained. There is plentiful evidence among Charleston's wives that they worked to reinforce the household's commitment to the urban commercial community. Roughly half of all liquor licences granted in the town were given to women like baker's wife Anne Bodell and shipwright's spouse Susannah Pritchard. ${ }^{16}$ Rachel Lawrence, wife of woodcarver William, announced that

having obtained credit from some merchants in Charlestowne in order to carry on business on her own proper accounts, as sole dealer and separate trader, exclusive and free from any concern with her husband... she... makes this declaration ... and gives notice that she has opened a house of entertainment near the Beef Market where Mr. Doughty formerly, Mr. Cannon after, and Mr. Prince Lately have lived.

What she failed to mention was that the premises had been run previously not by Cannon himself, but by his wife Martha while her general contractor husband tended to his carpentry business and urban rental properties. ${ }^{17}$

Indeed, a married woman's economic contribution to the independent trading household was so substantial that it frequently allowed her

12 Hunt, Middling Sort, 58-62; on growing numeracy among American tradesmen see Patricia Cline Cohen, 'Reckoning with commerce: numeracy in eighteenth-century America', in John Brewer and Roy Porter (eds.), Consumption and the World of Goods (New York, 1993), 324.

13 Advertisement of John Blott, South Carolina Gazette and Country Journal, 29 Jan. 1768.

14 Testimony of Violetta Wyatt in the case of Richardson v. Wyatt, South Carolina Chancery Court Records, Bundle 10, No. 1, 1796, South Carolina Department of Archives and History.

15 Loyalist Records AO13, Daniel Manson, vol. 131(2), reel 133, mfm, Library of Congress.

16 Lists of liquor licences granted in South Carolina Gazette, 24 Apr. 1762, 11 May 1767, 3 May 1773 and 27 May 1783.

17 South Carolina Gazette, 6 Feb. 1762. 
to sustain a comfortable existence through any periods of widowhood that she may experience. ${ }^{18}$ Such was the career of sole trader Francis Ramadge - a remarkable woman who outlasted two moderately successful merchant husbands to become a fixture on the Charleston commercial scene. Ramadge arrived in the town in 1766, when she was married to merchant Newman Swallow. She imported millinery on her own account, and employed a woman to help her make goods 'in that branch'. Three years later, she diversified into the service sector, opening a boarding school where she taught English, writing, arithmetic, needlework, dancing and drawing. After the revolution, the now Mrs Ramadge left teaching to open a coffeehouse, boarding house and to sell groceries. By 1804, she had abandoned Charleston proper for a boarding house on Sullivan's Island. Over almost 30 years, Francis Ramadge had taken up just about every urban economic role available to her as she successfully sought financial security. ${ }^{19}$

Focusing on Charleston - a city in which half the population were enslaved African-Americans - it is also apparent that, while the prominence of slave labour in the New World could create a uniquely American social structure, it simultaneously encouraged transatlantic trends. Among Charleston's middling sorts, slaves extended the scope of the household within the urban economy because their labour could be deployed at all skill levels, providing a regular and relatively reliable source of household income. Thus, middling masters tended to own groups of slaves with skills that were in demand for public and private service. Carpenter James Cook's slaves included carpenters Frank and Jack, Frank's wife and daughter Hagar and Molly (who were a laundress and a seamstress respectively), a sawyer, a gardener, 'Hattie an excellent cook and house servant and her son Plato a working boy' and finally 'complete seamstress' Arabella and her four-year-old son Bob. ${ }^{20}$ Clockmaker Francis Gottier owned two bricklayers, Billy and Abraham, who were hired out for income. Carpenter Esaie Brunet owned barber Jack, and silversmith Alexander Petrie had no less than three slave carpenters, a barber, a tailor and a cook. ${ }^{21}$

\section{A middling culture}

By taking advantage of the business opportunities on offer in a growing town, a section of white Charleston society had distinguished themselves as middling independent trading householders. Soon enough,

18 Karin Wulf, Not All Wives: Women of Colonial Philadelphia (Ithaca, 2000).

19 Advertisements of Francis Ramadge, South Carolina Gazette, 21 Sep. 1765; South Carolina Gazette and Country Journal, 15 Dec. 1767; South Carolina Gazette and General Advertiser, 2 May 1783; City Gazette or the Daily Advertiser, 11 Feb. 1791; City Gazette, 20 Nov. 1804.

${ }^{20}$ Loyalist Records, AO13 James Cook, vol. 87(1), reel 86, mfm, Library of Congress.

${ }^{21}$ Inventory of Francis Gottier 23 Oct. 1784, vol. A, 1783-87, 254; Inventory of Esaie Brunet, 22 Nov. 1757, vol. 84, 325; Inventory of Alexander Petrie, 6 Mar. 1768, vol. X, 365, South Carolina Department of Archives and History. 
the economic experience of this sector of urban society began to spill over into the cultural sphere. For some, their hard won economic security became the basis on which they sought, and perhaps gained, admission to the cultural milieu of a local elite consisting of planters and the richest merchants. ${ }^{22}$ Postmaster, church organist and sometime merchant John Stevens and his wife (the sole proprietor of a coffeehouse) perpetually strove to be included in the 'genteel' social circles inhabited by their superiors. Stevens, however, was snubbed on many an occasion and it was clear that in comparison to other middling professionals, like Doctor John Murray, he remained on the periphery of polite society. ${ }^{23}$ Murray never retired from business to lead a life of leisure, but from the position of a man with secure but modest means, he revelled in the ease with which he was accepted into Charleston society, commenting that the town had 'all the eleganceys and conveniency of life in great variety and plenty, and people here seem to make the most of life. They are gay and extremely sociable and polite and are quite unacquainted with our European stiffness. ${ }^{24}$ Honing in on the question of the relationship between landed elites and other wealthy settlers, Murray further noted that the 'gentry is not taken notice of hear every one is ... upon a levell the knights with the private gentlemen and them with the one a nest pheasant if there [sic] circumstances are alike'. ${ }^{25}$

Nevertheless it is also evident that, like their urban British compatriots, many among Charleston's middling sorts placed equal, if not greater, import on cultural values that stemmed from their experiences as urban independent traders. As a result, there was a growing and visible group of middling South Carolinians who did not wish to be 'nest pheasants' with a leisured gentry, but instead wanted to see their own principles expressed in their extra-curricular pursuits. ${ }^{26}$ This middling cultural move was especially embodied in the founding of two clubs, whose altruistic aspirations contrasted strongly with the entertainment and conviviality that lay at the heart of the town's many other societies. The earliest, founded in the 1730s, was the South Carolina Society, about which it was noted that 'at first, it consisted not of the most opulent citizens, though many of these thereafter joined it, but of persons in modest stations, who held it an essential duty to relieve one another in such a manner as their

22 On the evolution of the South Carolina elite see Richard Waterhouse, A New World Gentry: The Making of a Merchant and Planter Class in South Carolina, 1660-1770 (New York, 1989).

${ }^{23}$ John Stevens letter book, 1768-70, MSS, Library Company of Philadelphia.

24 John Murray to his mother, undated, probably 1750s, Murray of Murraythwaite muniments, National Archives of Scotland.

25 John Murray to his mother, 7 Jan. 1750, Murray of Murraythwaite muniments, National Archives of Scotland.

${ }^{26}$ It should be noted here that local elites were often among the members of these societies, but their membership appears to have been more symbolic than active. Their presence also prevents us from interpreting these middling organizations as a reaction to exclusion from more elite clubs. On the charitable urges of the British middling sorts see Hunt, Middling Sort, 101-24. 
circumstances would admit'. ${ }^{27}$ This charitable remit also applied to the Fellowship Society, a club founded in 1766 by Charleston upholsterer Edward Weyman with the motto Posteri mea dona laudabunt or 'Prosperity commend my beneficence'.

Looking in more detail at Weyman's Fellowship Society reveals the extent to which Charleston's association reflected a larger middling charitable sensibility. Lacking any particular occupational allegiance, the club's participants were overwhelmingly town-dwelling merchants, retailers and craftsmen. The 1778 rolls of the Fellowship Society listed 159 'town members' and just 47 'country members', with a fair number of the latter identifiable as former urbanites who had clearly decided to keep up their links with the town through the Society. ${ }^{28}$ Although some elites, like Isaac and John Huger, were on the membership rolls, regular and active participants were all middling tradesmen. None of the preRevolutionary officers in the Fellowship Society were leading members of South Carolina's elite-dominated governing body, the Commons House of Assembly, and in 1771 its president was carpenter James Brown, the junior warden goldsmith Thomas Harper, treasurer carpenter Blake Leay White, secretary merchant Edward Legge jr, and senior steward tailor John Rantowle.

The activities of the Fellowship Society were firmly grounded in the promotion of charity, religiosity and morality. There were, of course, leisured elements to its activities, and, like other associations, members met in the 'long rooms' of Charleston's taverns and took advantage of the food and alcohol furnished by the landlord. However, the club's minutes show that its officers were anxious to uphold the moral and religious reputations of their associates in a way that was of little concern to the members of Charleston's more elite organizations. Instead of attending star-studded concerts or eating sumptuous dinners, meetings were spent listening to sermons given by local Anglican and dissenting ministers. Leftovers from meals were donated to Charleston's poor house and gaol, and indulging in too much drink at such events could easily result in exclusion from the society. There was also a general concern that subscribers should uphold the good name of the organization through their wider deportment on the urban stage. As a result, John Pooley was asked to 'answer for his impudent conduct' on the basis that 'he had made use of very unbecoming expressions reflecting on the conduct of the society and the secretary thereof in public company out of doors' ${ }^{29}$

27 Alexander Hewitt, An Historical Account of the Rise and Progress of the Colonies of South Carolina and Georgia, 2 vols. (London, 1779), vol. I, 299.

${ }^{28}$ Records of the Fellowship Society, South Caroliniana Library; membership lists of the South Carolina Society, Charleston Orphan House Records, Charleston City Archive show that the founding of this institution stemmed from the same imperative.

${ }^{29}$ Minutes of the Fellowship Society, 20 Sep. 1769, for alcoholic overindulgence, 13 Jun. 1770, 6 Dec. 1769, 'left over victual to be sent to the gaol'. The membership rolls of the Fellowship Society include many names against which the word 'excluded' had been entered, and 
Rather than spend membership dues on French violinists and rum, monies were used to purchase town lots on which were raised poor hospitals, charity schools and low-rent tenements for needy Charleston families; the donations made by individuals for these causes were drafted into service as a pointed example to others through the publication of thanks in the local newspaper. ${ }^{30}$

As permanent town residents, whose financial assets, businesses and families were rooted in Charleston, the men of the Fellowship Society channelled their extra money and free time towards the improvement of their town and the lifting up of their fellow citizens. Such charitable and moral principles also went with these middling men to the grave. Underlining how a rejection of elite cultural models could comfortably coexist with the institution of slavery, cabinetmaker John Prue commanded in his will that his chattel labourer Jerry should be sold, and the proceeds donated to the South Carolina Society for the education of poor white children. Prue also set up the first endowment for the foundation of a college at Charleston. In an expression of the transatlantic dimension of such charitable principles, dissenting merchant and shopkeeper Thomas Corker expressed a wish in his last testament of 1771 that a sum be sent back to his home town of Nantwich in Cheshire for the education of 20 poor boys of the parish. ${ }^{31}$ Across the urban British Atlantic, private pursuits of 'domestick order and prudential morality' spilled over into individual lives and public arenas, becoming a marker of middling tendencies to favour propriety over politeness.

And, as Charleston's middling sorts became surer of their separate goals and better defined as a group, we can also trace how pursuit of a distinct culture increasingly went hand-in-hand with a critique of the ways in which others spent their spare time and money. Particularly under attack was the elite's predisposition towards false emotions and over-consumption, and such behaviour was highlighted by commentators as the antithesis of the values to which the moral individual should aspire. ${ }^{32}$ Campaigning, as ever, for the cause of the tradesman, Daniel Defoe thus described an elite who had succumbed to 'vicious living, luxury and extravagance', but a 'middle station' composed of men of industry, application and sobriety. What is more, those middling tradesmen who strove to be gentlemen-tradesmen would only appear as 'brass wash'd

minutes include discussions to eject members on the grounds of drunk and disorderly behaviour, suggesting the importance of upstanding behaviour to these societies. Records of the Fellowship Society, MSS, South Caroliniana Library.

$30 \mathrm{Ibid} ., 19$ Apr. 1769, 'Received from Mr. Blake Leay White a donation of $£ 50$ currency ... the thanks be returned ... by publishing it in the newspaper.'

31 Will of John Prue, wills vol. 15, book B, 413, 1771-74, letter book of Josiah Smith Jr, Josiah Smith Jr to John Corker, Bristol, 5 Jun. 1771, mfm, University of North Carolina, Chapel Hill, Southern Historical Collection.

32 Hunt, Middling Sort, 193-218. 
over with silver'. ${ }^{33}$ Echoing Defoe's opinion, Peter Timothy's South Carolina Gazette carried a 1773 article proclaiming that

Every Tradesman is a Merchant, every Merchant is a Gentleman, and every Gentleman one of the Noblesse. We are a Country of Gentry, Populous generosorum: We have no such Thing as a common People among us: Between Vanity and Fashion, the Species is utterly destroyed. The Sons of our lowest Mechanics are sent to the Colleges of Philadelphia, England, or Scotland, and there acquire, with their Learning, the laudable Ambition of Becoming Gentle-Folkes, despite their paternal Occupations, and we are all solicitous for the more honourable Employments of Doctors, Lawyers, and Parsons; whilst the pretty little Misses at Home are Exercised in no Professions at all, except those of Music and Dancing, which... make them very agreeable Companions, but will render them very expensive Wives. ${ }^{34}$

Drawing together the various objections to the prevailing urbane and genteel culture of South Carolina, this barbed commentary on the cultural geography of the colony also placed in plain sight the terms on which, by the 1770s, Charleston's middling sorts and elites were now at cultural odds with one another. On one side stood the gentry and their lesser followers scrabbling, through their vanity and their devotion to the shallow manners of politeness, to make it on the British Atlantic stage. Ornamental wives and useless learning characterized the genteel family, who were no longer capable of making a worthwhile contribution to the advancement of civilization and wealth in South Carolina. But what was the implied alternative proffered by the author? It was the hard-working, entrepreneurial, charitable middling townsman, and his equally diligent wife; the characters who now, quite self-consciously, occupied this typical urban middling order.

\section{Civic politics}

Almost as soon as these middling values permeated the cultural landscape of Charleston, heralding the emergence of a new social group in the town, urban politics were also drawn into the equation. Indeed, to be fully effective, these cultural and moral ambitions had to be brought to the political stage. Although Charleston was not incorporated, there were authorities outside of the colonial assembly charged with the improvement and regulation of the urban environment, and commissions, each of about six men, oversaw markets, streets, the harbour, the workhouse and the wharves. These bodies were somewhat similar in purpose to those commissions established in the contemporary British town, and as such constituted an emerging arena in which portions of the urban population might seek influence over the machinations of local government. ${ }^{35}$ Posts

33 Daniel Defoe, The Complete English Tradesman, 2nd edn (London, 1727), 117.

34 South Carolina Gazette, 1 Mar. 1773.

35 Rogers, 'The middling sort in eighteenth-century politics', 149, 160. 
on Charleston's commissions were sought by many individuals within the city, leaving Governor Bull to note in 1770 'a turn which prevails more in this than any other province, which is a gratuitous execution of many branches of power under a desire of shewing a public spirit and easing the public expences'. Bull continued by making reference to the 'various commissioners' involved in town regulation and the 'laudable spirit' with which they generally undertook their responsibilities. ${ }^{36}$

From mid-century onwards, there emerged an exceptionally strong connection between middling traders and service on the town's commissions. Life as a tradesman and a civic political career united most clearly in one man, Daniel Cannon, a carpenter, contractor and urban landowner. ${ }^{37}$ Throughout most of his career, Cannon's commitment to the improving imperative, his trade and his prominence in the more formal channels of civic politics were inseparable as he served on many different commissions and ensured his family's financial security through the execution of numerous public works contracts. Cannon's situation in town government was far from unique. Planters were not frequently encountered on civic bodies and, between 1742 and 1779, few who identified themselves primarily with the countryside sought control through the mechanisms of urban government, leaving the task to those whose chief economic and social ties lay in the town. At the same time, those men who might count themselves as part of a colonial governing elite by virtue of their election to its Commons House of Assembly formed only 30 per cent of commissioners. Assemblymen who did also serve on Charleston's civic institutions were mostly found among the vestrymen or firemen; positions that enjoyed the most prestige but often did not involve themselves too deeply in the day-to-day order of the town. In short, men with a close connection to Charleston and no position within a colonial governing elite showed most interest in the machinery of minor

36 Some have dismissed urban government in South Carolina as inconsequential, but it is clear that contemporaries did not believe it to be so. As early as 1751, Governor Glen sought the limitation of the commissions' powers as they constituted 'a sort of corporation having perpetual succession'. As quoted in Jack P. Greene, The Quest for Power: The Lower Houses of Assembly in the Southern Royal Colonies, 1689-1776 (Chapel Hill, 1963), 254. 'Bull's representation of the colony, 1770', in Merrens (ed.), The Colonial South Carolina Scene, 269.

37 Records of the South Carolina Treasury, Public Ledges, 1775-77 and 1777-80, Accounts of the Public Treasury, South Carolina Department of Archives and History. Cannon also laid out a suburb of Charleston called Cannonborough during the 1790s. For links between tradesmen and civic politics elsewhere in colonial America see Pauline Maier, From Resistance to Revolution: Colonial Radicals and the Development of American Opposition to Britain (New York, 1972), 85-7; David Waldstreicher, In the Midst of Perpetual Fetes: The Making of American Nationalism, 1776-1820 (Chapel Hill and London, 1997), 24-5; Benjamin L. Carp, 'Fire of liberty: firefighters, urban voluntary culture, and the revolutionary movement', William and Mary Quarterly, 58 (2001), 781-818; Nash, Urban Crucible: The Northern Seaports. Although all of these historians have highlighted the connection between townspeople and radicalism, they have tended to assume that these townspeople were not middling, but 'popular' and drawn from among the lower ranks of urban society. 
local government. This authority was frequently reinforced by a tendency to serve on the town's commissions year in, year out. ${ }^{38}$

Gradually, the correlation between those Charlestonians who became commissioners, and those middling men who were also prominent in the construction of the town's middling, civic, culture, also increased. Private (or semi-public) urban cultures were now becoming politicized by their intersection with the colony's apparatus of domestic government. As a result, Fellowship and South Carolina Society members engrossed the posts available on the town commissions. Whereas before 1760, only 30 per cent of commissioners were also members of a charitable society, after this point the figure doubled to almost 60 per cent. With their domination of charitable societies and commission posts, one group of urbanites established themselves as a cornerstone of the town's public life. Men like blockmaker Barnard Beekman, tailor Theodore Tresevant, merchant Darby Pendergrass and bricklayer Timothy Crosby combined trade, the charitable cause and urban government together. For those like Daniel Cannon, Edward Weyman (the founder of the Fellowship Society) and Beekman, who also happened to be tradesmen, the remuneration that they were already receiving as a result of their prominence in public works only added to their investment in Charleston's civic life. ${ }^{39}$

Once securely installed within the lower echelons of urban government, middling men then began to use their position as a platform from which they might broadcast their philosophy of civic responsibility to a larger (and principally elite) audience. By the 1760s, this civic faction were making regular calls for the town to be incorporated so that it might be protected from the chaos wrought by a self-indulgent and inattentive colonial elite, a chaos made more perilous by the presence of such a large enslaved population. Letters written in support of incorporation began to appear in the South Carolina Gazette from 1763 onwards. In 1765, 'A Tradesman' suggested that the only solution to the woe of a poorly regulated town was to 'directly instruct our REPRESENTATIVES; petition the GENERAL ASSEMBLY for a proper law; apply for an ACT TO INCORPORATE THE TOWN' ${ }^{40}$ Accompanying such calls were pointed accounts of how well Charleston's conscientious middling commissioners were carrying out their duties as they carefully inspected markets and punished those unruly whites and (most importantly) slaves who refused to work towards the good of the town. Reports were also wont to imply that, even if the elites looked quite happy to fiddle as Rome burned, there

38 WPA transcripts of St Philip's vestry minutes, 1742-79, South Carolina Library; Walter B. Edgar and N. Louise Bailey et al. (eds.), Biographical Directory of the South Carolina House of Representatives (Columbia, SC, 1974-), vol. II.

39 Records of the Fellowship Society, South Carolina Library.

40 Letter from A Tradesman, South Carolina Gazette, 26 Jan. 1765. Also John Carpenter, South Carolina Gazette, 26 Feb. 1763. Presentments of the Grand Jury, 15 Jan. 1770, mfm, South Carolina Department of Archives and History for a further call. 
were some within Charleston who were willing to exert themselves in the cause of public morality and civic order. ${ }^{41}$

As in the economic and cultural spheres, the growing town had provided the conditions in which a middling identity might flourish. Hence, rather than having its roots in the imperial crisis that ensued after 1765, this existing political identity was reinforced by the onset of transatlantic conflict. In Britain itself, middling political factions had developed their distinctive ideologies during the 1770s through engagement with the issues of the empire and its associated problems. Kathleen Wilson has thus argued that emergent middling factions believed that 'the sources of the war and loss of the colonies lay in the same over mighty concentrations of power in the state and locality which allowed government to pursue measures that were contrary to the sense of the people'. Within the empire itself, and more particularly in Charleston, civic politics shaped responses to imperial disputes among middling sorts in the same way, making this dialogue between local and imperial into a British Atlantic phenomenon. ${ }^{42}$

The political identity of Charleston's middling faction began the process of reinforcement through Revolutionary crisis during South Carolina's Stamp Act protest, when radicals gathered in the town's streets for the first time against the policies of the British government. The leaders of this party were those very people most active in the town's government and its religious associations. Like other civic factions in Britain's towns, John Wilkes provided the focus for the Charleston radicals' 'coming out' on to the broader imperial stage. In particular, the opposition of these middling tradesmen to the Stamp Act was centred on a John Wilkes Club. The club drank 'loyal and patriotic toasts' to the 'celebrated Patriot[s] of Britain or America' and 'marched in a regular procession to town' being careful all the time to 'preserve the same good order and regularity as had been observed throughout the day'. When the Wilkes Club nominated representatives for the colony's Commons House of Assembly, they selected those men who clearly shared their civic interests like dissenter and town commissioner Hopkin Price, staunch commissioner Thomas Smith of Broad Street, and South Carolina's most prominent radical, Christopher Gadsden. Overall, it was impossible to drive a wedge between the principles and men of this Stamp Act protest, and the motivations of those who were increasingly active in urban government at the same time. Indeed, their demonstrations were, in equal measure, an expression of good order and upstanding

41 South Carolina Gazette, 31 Oct. 1774.

42 Wilson, The Sense of the People, 236, 373-5. Jack P. Greene has considered the relationship between British colonial authorities and the South Carolina Commons House of the assembly, but did not explore it beyond this, the highest layer of government in the colony. See 'The Gadsden election controversy and the revolutionary movement in South Carolina' and 'Bridge to revolution: the Wilkes fund controversy in South Carolina, 17691775 ', in Greene, Negotiated Authorities: Essays in Colonial Political and Constitutional History (Charlottesville, 1994), 328-49 and 394-428. 
conduct in Charleston's public spaces, and a pledge of allegiance to a transatlantic radical, patriot, ideology. ${ }^{43}$

Over a decade later in 1776, civic issues were still at the very centre of radical, middling politics in South Carolina. With relations between colony and metropole now on the brink of collapse, South Carolinians moved to frame their first constitution. Those ruling assemblymen who drew it up quickly came under attack, both for adopting the document without subjecting it to a popular vote, and for ensuring that power was firmly in the hands of a low country, Anglican elite. On this occasion townsmen's protests were not aimed at the British, but were instead primarily concerned with the actions of their native leadership. Placed on a back foot, South Carolina's ruling moderate Whigs chose an arena of urban government recently appropriated by the civic faction - the Charleston Grand Jury - to keep the radicals at bay. Hence, the April 1776 presentments of the Charleston Grand Jurors, normally an exercise whereby radical middling townsmen had pressed home the deplorable state of the town to the governing elites, became a lecture by moderates aimed at restoring proper, deferential, respect for their actions in the constitutional affair. The pseudo-magistrates were 'convinced that to live in a society without laws or a proper execution of them to restrain the licentious nature of Mankind is the greatest misery that can befal a people and must render any body of men in such a situation, but little superior to a Herd of Brutes'. They further warned

that through the evil effects of anarchy and confusion, the people might become an easy prey to the several designs of their invidious Enemies... we think every opposition to [the government's] operations or disregard to its authority, the worst criminality a mortal can be guilty of, highly offensive in the eyes of God, and of all just men and deserving the most exemplary punishment. And cannot but deplore the unhappy situation of any few amongst the people of this Colony who, through an ignorance of their true interests and just rights, and from a want of proper information of the real truth, may be misled by the artifice and cunning of their false and designing enemies, from a real sense of those benefits which our present Constitution has so amply provided for: Benefits, which are not confined or limited to any Ranks or degrees of men in particular but generally, equally, and indiscriminately extending to all, from the richest to the poorest, and which time and a little patient experience must soon evince.

Uncouth urban radicals were thus told to stay in their place, as 'every good Citizen must be happy in the Consideration of the Choice of those Officers, appointed in the Administration of our present Government'. Fed up with being needled about their immoral and luxurious indulgence in urbane pleasures, their inattention to the order of their town, and now also challenged about their leadership of South Carolina in international affairs,

43 Richard Walsh, Charleston's Sons of Liberty: A Study of the Artisans, 1763-1789 (Columbia, 1959), 70-1. 
elites struck back at the impertinence of their disobedient opponents using the very mouthpiece of their adversaries - the tools of urban order. ${ }^{44}$

\section{Conclusion}

It is, of course, an exercise in stating the obvious to say that across the British Atlantic world, the American Revolution (or the War of Independence) had complex causes and a multitude of repercussions for the lives of those caught up in the dispute. In other times and places, nonurban local disputes, conflicts between colonial centre and periphery, and between royal governors and assemblies, determined the course of events. Outside the confines of the European political arena, Indians and AfricanAmericans were vital to the texture of revolution in both backcountry and coastal regions, where revolutionary war became a battle for white superiority as slaves took up British offers of freedom, and Natives tried to use the disagreements among their trading partners to win back some of the land grabbed from them by settlers. Far from being a quest for freedom and democracy, the tumult of war became the opportunity for all and sundry to air grievances and stake claims. ${ }^{45}$

In South Carolina alone, the fact of a slave majority and the necessity of managing an unpredictable population of backcountry Loyalists influenced the actions and opinions of the colony's leading patriots as they proceeded to Philadelphia, first to the Continental Congress and later to the Constitutional Convention. ${ }^{46}$ However, South Carolina's leaders also journeyed northwards in the knowledge that they left behind in Charleston an increasingly restive middling sort who, while not influential enough to unseat them, were nevertheless demanding a role in the affairs of the colony as it moved towards statehood. Rather than being a process that furnished middling sorts with a new self-awareness, imperial crisis and revolution had availed urban tradesmen of the opportunity better to articulate grievances that they already harboured, and to develop civic political sensibilities already under construction.

The period between 1750 and 1780 witnessed the emergence of a British American middling sort in Charleston. Taking its character from its urban environment, this social group shared economic, cultural and political characteristics; features that also served to distinguish them

44 Presentments of the Grand Jury, 23 Apr. 1776, mfm, South Carolina Department of Archives and History.

45 Woody Holton, Forced Founders: Indians, Debtors, Slaves, and the Making of the American Revolution in Virginia (Chapel Hill, 1999); Greene, Quest for Power; Colin Calloway, The American Revolution in Indian Country: Crisis and Diversity in Native American Communities (Cambridge, 1995); Sylvia Frey, Water from the Rock: Black Resistance in a Revolutionary Age (Princeton, 1991).

46 Rachel N. Klein, Unification of a Slave State: The Rise of the Planter Class in the South Carolina Backcountry, 1760-1808 (Chapel Hill, 1990); Jerome J. Nadelhaft, The Disorders of War: The Revolution in South Carolina (Orono, 1981); Rebecca Starr, A School for Politics: Commercial Lobbying and Political Culture in Early South Carolina (Baltimore, 1998). 
from their gentry betters. Often, these were values that middling sorts themselves sought to stress so that they might be separate from elites with whom they did not wish to be too closely associated. The ease with which we can trace the emergence of this New World middling sort without venturing into the field of imperial disputes lends weight to the idea that the foundations of this social group are separable from America's particular experience. To a large extent, this middling sort was forged out of an environment of increased urban growth and prosperity that spanned the British Atlantic world and existed independent of the radicalism of the American Revolution and the particular configuration of colonial society. These were processes that did not emerge from America's peculiarly truncated or 'loose' societal structure, but from universal urban opportunity across the British Atlantic. ${ }^{47}$ As in Britain, the burgeoning urban landscape (itself the fruit of Atlantic trade) had proved to be a vital source of change, enabling Josiah Quincy to identify Charleston's middling people as an 'odious' collective. To an elite northern lawyer, travelling south for his health, middling Charlestonians' strong commitment to their own agenda of urban order and good works, and their open disapproval of elite culture and political power, had made them a very unpleasant proposition indeed.

47 Wood, Radicalism of the American Revolution. 